\title{
Catalytic degradation of real-textile azo-dyes in aqueous solutions by using $\mathrm{Cu}-\mathrm{Co} / \mathrm{halloysite}$
}

\author{
JUAN A TORRES-LUNA ${ }^{1}$, GLORIA I GIRALDO-GÓMEZ ${ }^{2}$, NANCY R SANABRIA-GONZÁLEZ ${ }^{3}$ \\ and JOSÉ G CARRIAZO',* \\ ${ }^{1}$ Estado Sólido y Catálisis Ambiental (ESCA), Departamento de Química, Facultad de Ciencias, Universidad Nacional de \\ Colombia, 111321 Bogotá, Colombia \\ ${ }^{2}$ Facultad de Ciencias Exactas y Naturales, Universidad Nacional de Colombia Sede Manizales, Campus La Nubia, km 7 \\ via al Magdalena, AA 127 Manizales, Colombia \\ ${ }^{3}$ Facultad de Ingeniería y Arquitectura, Universidad Nacional de Colombia Sede Manizales, Campus La Nubia, km 7 via \\ al Magdalena, AA 127 Manizales, Colombia \\ *Author for correspondence (jcarriazog@unal.edu.co)
}

MS received 17 September 2018; accepted 27 November 2018; published online 29 April 2019

\begin{abstract}
Catalytic degradation of textile dyes in diluted aqueous solutions with minimal consumption of energy is a great challenge for wastewater treatment and environmental protection. Efficient heterogeneous catalysts are needed to completely oxidize azo-dyes under soft conditions. In this work, catalysts of $\mathrm{Cu}-\mathrm{Co}$ oxide (1:2 molar ratio) supported on halloysite $(\mathrm{Ha})$ nanotubes $(\mathrm{CuCo}(5 \%) / \mathrm{Ha}$ and $\mathrm{CuCo}(10 \%) / \mathrm{Ha})$ were synthesized and used in the catalytic wet peroxide oxidation of reactive yellow 145 (RY-145) and basic red 46 (BR-46). The catalysts were characterized by chemical analysis, $\mathrm{X}$-ray diffraction, Raman spectroscopy, $\mathrm{N}_{2}$ adsorption isotherms, scanning electron microscopy and transmission electron microscopy. The results showed that the synthesized catalysts possess nanotubular structure with good mesoporosity, and the spinel structure $\mathrm{CuCo}_{2} \mathrm{O}_{4}$ was identified as the active phase deposited on Ha. The catalysts degraded these azo-dyes in diluted solutions ( $22 \mathrm{mg}^{-1}$ of RY-145 and $35 \mathrm{mg} \mathrm{l}^{-1}$ of BR-46) under mild reaction conditions $\left(25^{\circ} \mathrm{C}\right.$, atmospheric pressure, $\mathrm{pH} 4$ and minimum amounts of both catalyst and $\left.\mathrm{H}_{2} \mathrm{O}_{2}\right)$. Significant levels of dye conversion $(93.1 \pm 2.2 \%$ for RY-145 and 54.4 $\pm 2.0 \%$ for BR-46) were achieved in a relatively short time. In addition, significant values of total organic carbon removal $(59.5 \pm 1.8 \%$ for RY-145 and $33.9 \pm 1.4 \%$ for BR-46) were obtained, indicating the total oxidation of a significant fraction of these dyes to $\mathrm{CO}_{2}$ and $\mathrm{H}_{2} \mathrm{O}$.
\end{abstract}

Keywords. Halloysite; $\mathrm{Cu}-\mathrm{Co}$ oxide; catalytic wet peroxide oxidation; azo-dye; textile dye.

\section{Introduction}

Wastewater treatment is an important concern to ensure, in modern life, a healthy environment. Inorganic and organic pollutants must be removed from wastewaters from various human activities, before such residual waters can be discharged into different natural sources or municipal sewerage systems [1]. Pollution in water resources is usually associated with the discharge of wastewaters from domestic, agricultural and industrial activities [2]. Several industries, such as petroleum refineries, chemical, agrochemical, petrochemical, paper and pulp, pharmaceutical and textile factories frequently release organic contaminants into water [3]. Organic pollutants are dangerous because they increase the chemical oxygen demand and alter the $\mathrm{pH}$ of water in ecosystems. Additionally, some of them are toxic or alter the metabolism of certain biological species [4]. Textile factories produce different dyes dissolved in water at diverse stages of the dyeing process. According to the literature, it is estimated that about $10-25 \%$ of dyes used in textile factories are lost during the dyeing process, and between 2 and $20 \%$ is directly discharged as aqueous effluents in different ecosystems [2,3]. Some textile dyes dissolved in water, e.g., azo-compounds are toxic, mutagenic and carcinogenic [5-8], causing serious environmental problems. Besides, all dyes give highly coloured appearance to water sources, causing a variation in their natural aesthetic perception, blocking sunlight transmission and decreasing photosynthesis [8,9]. Since textile dyes have high-molar absorption coefficients, even a very small amount of dye in water $\left(<1 \mathrm{mg} \mathrm{l}^{-1}\right)$ is highly visible, affecting the transparency of water bodies [10].

Among the different types of dyes, azoic compounds are widely used in the textile industry. Azo-dyes have one or more azo groups $\left(\mathrm{R}_{1}-\mathrm{N}=\mathrm{N}-\mathrm{R}_{2}\right)$ and various aromatic rings in their chemical structure. They currently represent $>50 \%$ of the global production of dyes [11-13]. In general, $>10,000$ different dyes and pigments are used in the textile industries, reaching a total world production near 2,000,000 tonnes a year [14]. Since these data reveal a high level of industrial consumption of textile dyes, the magnitude of the problem derived 
from wastewaters discharged by textile factories is serious. Two important azo-dyes extensively used in textile factories are 'reactive yellow 145' (RY-145), an anionic colourant in water, and 'basic red 46' (BR-46), a cationic colourant in aqueous solutions. RY-145 is employed in dye cotton clothes, whereas BR-46 is used for dyeing nylon, acrylic and woollen clothes [15,16]. Great endeavours have been performed to achieve removal, decolourization or total degradation of azodyes in wastewaters. Several methods, such as adsorption $[6,17]$, biosorption [18], biological treatments by bacterial culture and fungal species [11,19], microwave irradiation [16], photocatalytic oxidation [2,10,20], wet oxidation [21], catalytic wet ozonation [22] and catalytic wet peroxide oxidation (CWPO) [23,24] have been employed to eliminate these textile dyes. Typically, azo-dyes are toxic compounds, non-biodegradable or difficult to be biodegraded. They are physico-chemically stable under sunlight and mild thermal treatments, which makes difficult the elimination of these pollutants from diluted wastewaters. Particularly, RY-145 and BR-46 (figure 1) are very recalcitrant, and thus, very stable and difficult to be totally degraded to $\mathrm{CO}_{2}$ and $\mathrm{H}_{2} \mathrm{O}$.

Among the aforementioned methods, only the catalytic and physical adsorption methods are most suitable to efficiently remove these colourants, because of their toxicity and chemical stability. Adsorbents and catalysts are important resources for sustainable development in industrial wastewater treatments, with low-energy consumption and formation of less harmful byproducts. In particular, catalysts play an essential role in the so-called combined or integrated approach to environmental protection [25]. Adsorption is not very effective when organic pollutants are present in diluted media. Thus, catalytic methods are preferable for the removal of textile azo-dyes because they oxidize these organic compounds to $\mathrm{CO}_{2}$, nitrate anions and water, among others. Recently, advanced oxidation processes (AOPs) have been used for the degradation/mineralization of azo-dyes and a wide class of organic compounds. AOPs are characterized by the in situ generation of hydroxyl $(\mathrm{OH})$ and perhydroxyl $\left(\mathrm{HO}_{2}{ }^{\circ}\right)$ radicals, which are very reactive and non-selective to attack organic molecules and oxidize them to $\mathrm{CO}_{2}[23,24,26]$. Several methods, such as photolysis $\left(\mathrm{UV} / \mathrm{H}_{2} \mathrm{O}_{2}\right)$, catalytic ozonation, photocatalysis, classical Fenton's reaction (involving a homogeneous solution of $\mathrm{Fe}^{2+} / \mathrm{H}_{2} \mathrm{O}_{2}$ ), photo-Fenton system $\left(\mathrm{Fe}^{2+} / \mathrm{H}_{2} \mathrm{O}_{2} / \mathrm{UV}\right)$ and Fenton-type reactions (involving $\mathrm{H}_{2} \mathrm{O}_{2}$ and solid iron species, other ions or solids different from iron species) are classified as AOPs [10,26-28]. CWPO (catalyst $/ \mathrm{H}_{2} \mathrm{O}_{2}$ ) is typically an advanced oxidation process. The use of heterogeneous catalysts based on solid species of iron oxide, cerium oxide, manganese oxide, cobalt oxide and copper oxide has been previously published [24,26,29-33]. Due to some drawbacks observed for iron oxides, such as low $\mathrm{pH}$ of the reaction, and significant leaching levels of iron ions, other oxides have attracted the attention of researchers. Thus, the remarkable results obtained by using these oxides have encouraged new research work. Importantly, copper and cobalt oxides are attractive because they have shown a good
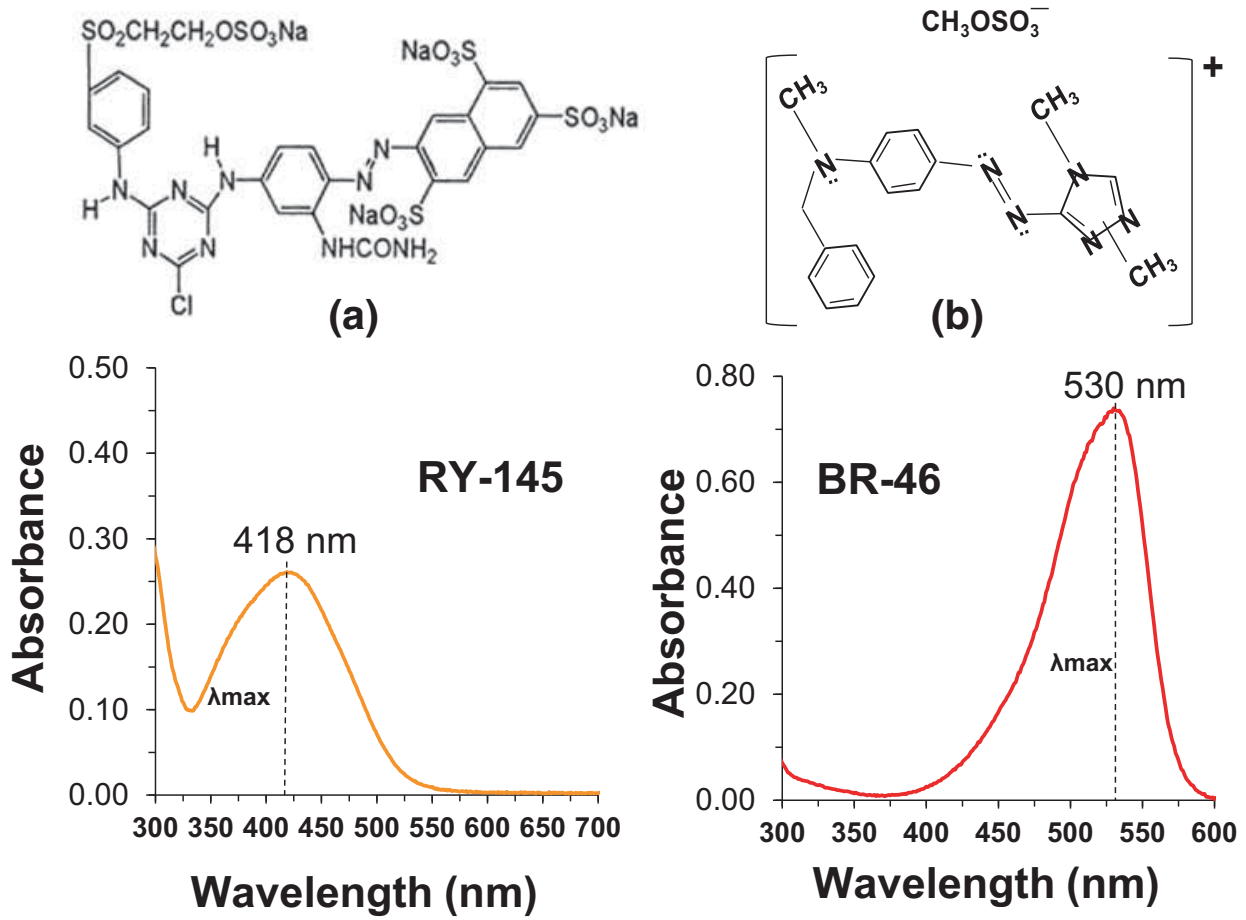

Figure 1. Molecular structures and UV-Vis spectra of the azo-dyes studied in the present work: (a) RY-145 and (b) BR-46. 
performance in the CWPO of recalcitrant organic molecules, having higher $\mathrm{pH}$ values than that of iron oxides and obtaining very low values of metal leaching [24,29,32,34]. Furthermore, an important cooperative effect has recently been confirmed between copper and cobalt in supported copper-cobalt mixed oxides when this system was used as a catalyst for oxidation reactions and for the decomposition of $\mathrm{H}_{2} \mathrm{O}_{2}[31,35,36]$. Accordingly, the supported copper-cobalt mixed oxide might be a promising catalyst to be employed in the CWPO of textile azo-dyes.

On the other hand, different catalytic supports have been used to design heterogeneous catalysts for CWPO. Hence, activated carbons, ashes, polymeric resins, zeolites, clay minerals, pillared clays, alumina, silica, among others have been studied [25,26,29,32]. The support chosen should have several characteristics such as a good surface area, porosity, chemical stability and favourable particle morphology and size. Clay minerals are versatile green materials with attractive properties for this purpose. Halloysite $(\mathrm{Ha})$ is an interesting 1:1 clay mineral (1:1 aluminosilicate) with a nanotubular structure. This natural material has a tetrahedral sheet of silicates $\left(\mathrm{SiO}_{4}\right.$ units) covalently bonded to an octahedral sheet of hydrated alumina $\left(\mathrm{AlO}_{6}\right)$ (both $\mathrm{Si}^{4+}$ and $\mathrm{Al}^{3+}$ species coordinated with oxygen and/or hydroxyl groups) to form complete 1:1 layers [37]. In this clay mineral, layers are rolled to form nanometric tubular structures. Along these lines, the use of $\mathrm{Ha}$ as a catalytic support in CWPO reactions for textile azo-dye degradation is an interesting and innovative approach. These nanotubes improve the dispersion of active phases (metal oxides) and the molecular transport of reagents. Consequently, the objective of this work was to synthesize copper-cobalt mixed oxides supported on Ha nanotubes to be used as heterogeneous catalysts for the oxidative degradation of two textile azo-dyes, RY-145 and BR-46, in water. This process has been carried out in diluted aqueous solutions using diluted hydrogen peroxide and mild conditions of temperature and pressure.

\section{Materials and methods}

\subsection{Chemicals and materials}

Azo-dyes (RY-145, molecular formula: $\mathrm{C}_{28} \mathrm{H}_{20} \mathrm{ClN}_{9} \mathrm{Na}_{4}$ $\mathrm{O}_{16} \mathrm{~S}_{5}, 1026.25 \mathrm{~g} \mathrm{~mol}^{-1}$, CAS number: 93050-80-7; and BR46, molecular formula: $\mathrm{C}_{19} \mathrm{~N}_{6} \mathrm{H}_{24} \mathrm{O}_{4} \mathrm{~S}, 432 \mathrm{~g} \mathrm{~mol}^{-1}$, CAS number 12221-69-1) were purchased from Ciba-Geigy, and supplied by a local enterprise (Bogotá, Colombia). They were later used without any further purification. Sulphuric acid (97\%), sodium hydroxide ( $\geq 99 \%)$ and $\mathrm{H}_{2} \mathrm{O}_{2}(30 \mathrm{w} / \mathrm{v} \%)$ were purchased from Merck (Darmstadt, Germany). Nitrate salts, $\mathrm{Co}\left(\mathrm{NO}_{3}\right)_{2} \cdot 6 \mathrm{H}_{2} \mathrm{O}(99 \%)$ and $\mathrm{Cu}\left(\mathrm{NO}_{3}\right)_{2} \cdot 3 \mathrm{H}_{2} \mathrm{O}(99 \%)$, were supplied by Panreac (Barcelona, Spain). Distilled/deionized water was used for the preparation of all solutions. Ha was extracted from Mondoñedo, a mine located near Bogotá, Cundinamarca (Colombia). This mineral was ground and sieved through ASTM-100 mesh before being used in the synthesis of catalysts. This $\mathrm{Ha}$ has been previously characterized in other studies [36,38].

\subsection{Synthesis of solids}

Two catalysts composed of mixed copper-cobalt oxides supported on Ha were synthesized by wet co-impregnation from an aqueous solution of nitrate salts. In both cases, the required amounts of copper and cobalt were dissolved in a minimum volume of deionized water, maintaining a $\mathrm{Cu}$ :Co molar ratio of 1:2. An appropriate volume of this solution was added to a suspension of $\mathrm{Ha}$ in deionized water $(20 \mathrm{~g}$ per $50 \mathrm{ml})$ to obtain a nominal load of metal $(\mathrm{Cu}+\mathrm{Co})$ of 5 and $10 \%$ in solid catalysts. Each mixture was subjected to magnetic stirring at $40^{\circ} \mathrm{C}$ to reduce the initial volume to half, and then the total solvent was evaporated at $60^{\circ} \mathrm{C}$. The obtained solids were dried in an oven at $60^{\circ} \mathrm{C}$ for $24 \mathrm{~h}$ and calcined at $400^{\circ} \mathrm{C}$ for $2 \mathrm{~h}$ under a static air atmosphere. Finally, the calcined solids were crushed and passed through an ASTM-100 mesh to obtain powders. These catalysts are labelled as $\mathrm{CuCo}(5 \%) / \mathrm{Ha}$ and $\mathrm{CuCo}(10 \%) / \mathrm{Ha}$. Similarly, but without $\mathrm{Ha}$, a mixed oxide of copper-cobalt was obtained by the evaporation of the total water from a mixed solution ( $\mathrm{Cu}$ :Co molar ratio of 1:2). The solid was also dried at $60^{\circ} \mathrm{C}$ for $24 \mathrm{~h}$ and calcined at $400^{\circ} \mathrm{C}$ for $2 \mathrm{~h}$ under a static air atmosphere. This material was used as a reference for X-ray diffraction (XRD) and Raman spectroscopy characterization.

\subsection{Characterization of solids}

The chemical analysis of solids was carried out by X-ray fluorescence, using a MagixPro PW-2440 Philips spectrometer with a rhodium tube and a maximum power of $4 \mathrm{~kW}$. The profiles of XRD were recorded using a Panalytical X'Pert PRO MPD equipment with a copper anode $(\mathrm{CuK} \alpha$ radiation: $\lambda=1.54056 \AA$ ). All diffractograms were taken at room temperature with $0.02^{\circ}(2 \theta)$ step size and $10 \mathrm{~s}$ step time. Raman spectra (resolution of $1.9 \mathrm{~cm}^{-1}$ ) were measured with a Thermo Scientific DXR Raman microscope at room temperature using a laser light of $532 \mathrm{~nm}$ and a power of $8 \mathrm{~mW}$ with a slit of $50 \mu \mathrm{m}$ (spectrograph aperture). Scanning electron micrographs (SEM) were obtained using a FEI Quanta 200 microscope, capturing several images and energy-dispersive X-ray (EDX) profiles at different points of the solids. The samples were metallized with Au, by sputtering (Quorum Q150R ES equipment) before their examination. Transmission electron microscopy (TEM) analysis was performed using an FEI electronic microscope (TECNAI 20 Twin, $200 \mathrm{kV}$ model). The textural properties of the solids were determined via $\mathrm{N}_{2}$ adsorption-desorption, using a Micromeritics ASAP 2020 equipment. Samples were previously degassed at $200^{\circ} \mathrm{C}$ for $4 \mathrm{~h}$. The isotherms were taken at $77 \mathrm{~K}$, in a range of relative pressures $\left(P / P_{0}\right)$ between $1 \times 10^{-5}$ and 0.99 . The surface areas were determined by using the Brunauer-Emmett-Teller (BET) model, and the total pore volumes were calculated with the Gurvitsch method. The Barrett-Joyner-Halenda (BJH) 
model was applied for the distribution of pore sizes, using the desorption branch (ASTM designation: D4641-88).

\subsection{Catalytic experiments}

Catalytic experiments were performed in a glass semi-batch reactor of $400 \mathrm{ml}$ capacity, covered with an aluminium foil to avoid any photo-assisted effect. For each catalytic test, the reactor was loaded with $225 \mathrm{ml}$ of a dye solution $\left(22 \mathrm{mg} \mathrm{l}^{-1}\right.$ for RY-145 or $35 \mathrm{mg}^{-1}$ for BR-46 in deionized water) and $80 \mathrm{mg}$ of catalyst. Before addition of the catalyst, the system was thermostated at $25^{\circ} \mathrm{C}$ (thermostat Lauda E 200 Ecoline), at atmospheric pressure and under constant magnetic stirring (350 rpm, in hotplate stirrer DLAB MS-H280-Pro). The $\mathrm{pH}$ was continuously registered with a $\mathrm{pH}$-meter (SI Analytics Lab 845), and a value close to 4 was maintained during the reaction by the addition of small drops of $0.1 \mathrm{M} \mathrm{NaOH}$ or $0.1 \mathrm{M} \mathrm{H}_{2} \mathrm{SO}_{4}$ solution. A diluted solution $(0.15 \mathrm{M})$ of hydrogen peroxide was added to the reactor using a peristaltic pump (Masterflex C/L model 77120-62) with a flux of $1 \mathrm{~m} \mathrm{~h}^{-1}$. In addition, dry air was bubbled $\left(31 \mathrm{~h}^{-1}\right)$ during the catalytic test. The monitoring time of each reaction was $7 \mathrm{~h}$ (excluding the time for dye adsorption-desorption equilibrium). Before each reaction, an adsorption period ( $2 \mathrm{~h}$ for RY-145 or $3 \mathrm{~h}$ for BR-46, previously established by several experiments) takes place for the catalysts in the dye solution. After the adsorption plateau, new concentrations of dyes were measured (18 $\mathrm{mg} \mathrm{l}^{-1}$ for RY-145 and $23 \mathrm{mg} \mathrm{l}^{-1}$ for BR-46) and taken into account as initial concentrations to calculate the catalytic conversions. The zero time of each reaction was established when the addition of hydrogen peroxide (followed by air) was initiated.

The catalytic degradation (oxidation) of dyes was monitored by UV-Vis spectroscopy (UV-1200 spectrophotometer, Shanghai Mapada Instruments Co., Ltd., China). The conversion of dyes was determined from the absorbance at the maximum absorption wavelength (418 nm for RY-145 and $530 \mathrm{~nm}$ for BR-46), measured with aliquots ( $1 \mathrm{ml}$ of sample filtered with $0.45 \mu \mathrm{m}$ Millipore paper) extracted at different times of reaction. A calibration curve relating absorbance vs. dye concentration (Lambert-Beer law) was used in each case. Correlation coefficients $\left(R^{2}\right)$ of 0.9987 (RY-145) and 0.9994 (BR-46) between 0.5 and $35 \mathrm{mg} \mathrm{l}^{-1}$ were observed. Detection limit (DL) and quantification limit (QL) were: $\mathrm{DL}=0.041 \mathrm{mg} \mathrm{l}^{-1}$ and $\mathrm{QL}=0.138 \mathrm{mg} \mathrm{l}^{-1}$ for RY-145, and $\mathrm{DL}=0.304 \mathrm{mg} \mathrm{l}^{-1}$ and $\mathrm{QL}=1.01 \mathrm{mg} \mathrm{l}^{-1}$ for BR-46. All the catalytic experiments were carried out in triplicate, and the experimental error was estimated to be between 2 and $4 \%$. The conversion percentage of the dye was calculated from the following equation:

$$
\text { Dye conversion }(\%)=\frac{\left(C_{0}-C_{\mathrm{t}}\right)}{C_{0}} \times 100 \text {, }
$$

where $C_{0}\left(\mathrm{mg} \mathrm{l}^{-1}\right)$ is the initial concentration of dye and $C_{\mathrm{t}}\left(\mathrm{mg} \mathrm{l}^{-1}\right)$ is the concentration of dye at time $t$. In addition, the total oxidation (mineralization) of these pollutants was determined by quantifying both the total organic carbon (TOC) and the total nitrogen (TN) in an automated equipment Multi N/C 3100 (Analytik Jena AG Co., Germany). Calibration curves using standard solutions of potassium hydrogen phthalate ( $\geq 99.5 \%$, Merck, Darmstadt, Germany) and potassium nitrate/ammonium sulphate $(\geq 99.0 \%$, Merck, Darmstadt, Germany) were obtained. The DLs calculated were $4 \mu \mathrm{g}^{-1}$ and $0.05 \mathrm{mg} \mathrm{l}^{-1}$ for TOC and TN, respectively, and experimental errors were less than $2 \%$ for TOC and $3 \%$ for TN. Metal leaching of the catalysts was measured with a Thermo Scientific iCE 3000 Series atomic absorption spectrometer.

\section{Results and discussion}

\subsection{Characterization of solids}

The chemical analysis (table 1) of natural Ha verifies the presence of constituting elements in this mineral. The results revealed a typical $\mathrm{SiO}_{2} / \mathrm{Al}_{2} \mathrm{O}_{3}$ ratio of 1.31 and other elements in small amounts, confirming the composition obtained in previous studies $[36,38]$. This ratio is higher than the theoretical ratio of 1.2 obtained from the chemical formula of $\mathrm{Ha}, \mathrm{Al}_{2} \mathrm{Si}_{2} \mathrm{O}_{5}(\mathrm{OH})_{4}$. From this consideration and taking into account that the chemical analysis of Ha yielded $48.5 \%$ of $\mathrm{SiO}_{2}$ and $37.0 \%$ of $\mathrm{Al}_{2} \mathrm{O}_{3}$, an extra-framework $\mathrm{SiO}_{2}$ content of about $4 \%$ can be estimated. $\mathrm{A} \mathrm{Cu} / \mathrm{Co}$ ratio close to 0.5 confirms the nominal copper:cobalt ratio (1:2) incorporated in the catalysts in accordance with the preparation. X-ray powder diffraction analysis (figure 2) shows the typical signals of Ha, interplanar spacings $\left(d_{\mathrm{hkl}}\right)$ of $7.3 \AA$, $\left(d_{001}\right)$ of $4.4 \AA$ and $\left(d_{002}\right)$ of $3.6 \AA$ confirming the structure of this clay used as

Table 1. Chemical analysis of $\mathrm{Ha}$ (fresh) and synthesized catalysts.

\begin{tabular}{lcccccc}
\hline Solid & $\mathrm{SiO}_{2} / \mathrm{Al}_{2} \mathrm{O}_{3}$ & $\mathrm{Cu} / \mathrm{Co}$ & $\mathrm{Fe}_{2} \mathrm{O}_{3}(\%)$ & $\mathrm{TiO}_{2}(\%)$ & $\mathrm{K}_{2} \mathrm{O}(\%)$ & $\mathrm{MgO}(\%)$ \\
\hline $\mathrm{Ha}$ & 1.31 & - & 0.52 & 1.00 & 0.12 & 0.22 \\
$\mathrm{CuCo}(5 \%) / \mathrm{Ha}$ & 1.32 & 0.49 & 0.63 & 0.20 & 0.20 & 0.09 \\
$\mathrm{CuCo}(10 \%) / \mathrm{Ha}$ & 1.24 & 0.59 & 0.67 & 0.20 & 0.20 & 0.05 \\
\hline
\end{tabular}




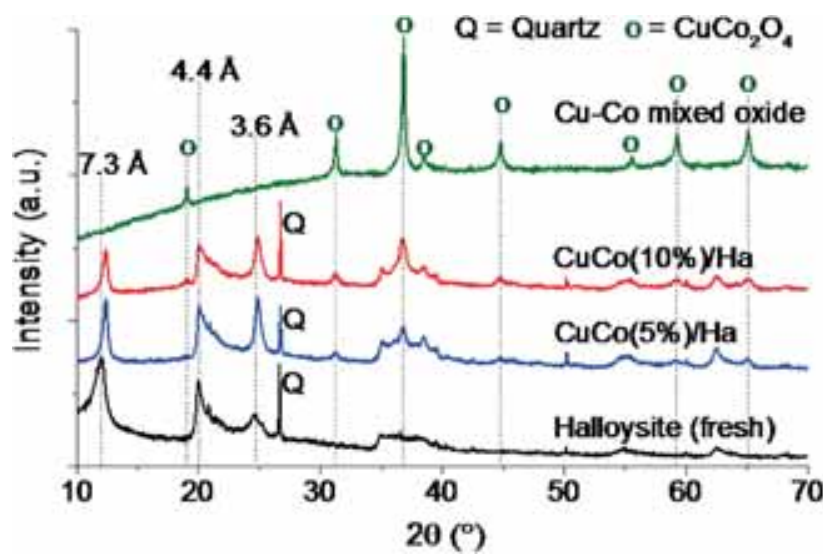

Figure 2. X-ray powder diffraction profiles of the synthesized solids and $\mathrm{Ha}$ (fresh).

a support [37]. A small amount of quartz $\left(\mathrm{SiO}_{2}\right.$ impurity) was also detected, in agreement with the chemical analysis of Ha. The most intensive peak of quartz is observed at $2 \theta=26.6^{\circ}\left(d_{\mathrm{hkl}}=3.3 \AA\right)$, and labelled as $Q$ in the diffractograms. The catalysts also contain a small content of quartz originating from the support. The high intensity of the $Q$ peak results from the high crystallinity of quartz, because the quantity of quartz is $<4 \%$ in $\mathrm{Ha}$. The XRD signals from $\mathrm{Ha}$ were clearly observed in the diffraction patterns of the catalysts $\mathrm{CuCo}(5 \%) / \mathrm{Ha}$ and $\mathrm{CuCo}(10 \%) / \mathrm{Ha}$, indicating that $\mathrm{Ha}$ maintains its structure after preparation and calcination of the catalysts. In addition, a small displacement of the $d_{001}$ peak in the catalysts is a result of the unit cell contraction in that dimension due to calcination. The higher intensity of the $d_{002}$ peak of $\mathrm{Ha}$ in the catalysts is a consequence of increasing the arrangement of the (002) planes. On the other hand, regarding the profile of $\mathrm{Cu}-\mathrm{Co}$ mixed oxide (figure 2), all the diffraction peaks observed at $2 \theta(h k l)=19.0^{\circ}(111), 31.2^{\circ}(220)$, $36.8^{\circ}(311), 38.5^{\circ}(222), 44.8^{\circ}(400), 55.5^{\circ}(422), 59.3^{\circ}(511)$ and $65.0^{\circ}(440)$ are attributed to the formation of $\mathrm{CuCo}_{2} \mathrm{O}_{4}$, a substituted spinel-type structure $[36,39,40]$. Some of these peaks are clearly observed in the XRD profiles of the catalysts $\mathrm{CuCo}(5 \%) / \mathrm{Ha}$ and $\mathrm{CuCo}(10 \%) / \mathrm{Ha}$, revealing the formation of this $\mathrm{Cu}-\mathrm{Co}$ structure on the Ha nanotubes. In particular, the peaks at $31.2,36.8,44.8,59.3$ and $65.0^{\circ}$ emerged in the XRD patterns of the catalysts as a result of their higher intensity from the $\mathrm{CuCo}_{2} \mathrm{O}_{4}$ structure. These results indicate that the $\mathrm{CuCo}_{2} \mathrm{O}_{4}$ structure corresponds to the active sites of these catalysts.

Raman spectra of the catalysts (figure 3 ) provide valuable information on the structure of copper-cobalt active sites. The five signals at about 160, 450, 500, 595 and $660 \mathrm{~cm}^{-1}$ correspond to the structural symmetries $F_{2 g}, E_{g}, F_{2 g}, F_{2 g}$ and $A_{1 g}$, respectively. They represent Raman active vibration modes characteristic of the cobalt spinel structure or its substituted spinels [41-43]. The most intense band $\left(660 \mathrm{~cm}^{-1}\right)$, associated with the symmetry $\mathrm{A}_{1 \mathrm{~g}}$, is attributed to the vibration of octahedral sites [41], whereas the band at $160 \mathrm{~cm}^{-1}$ is

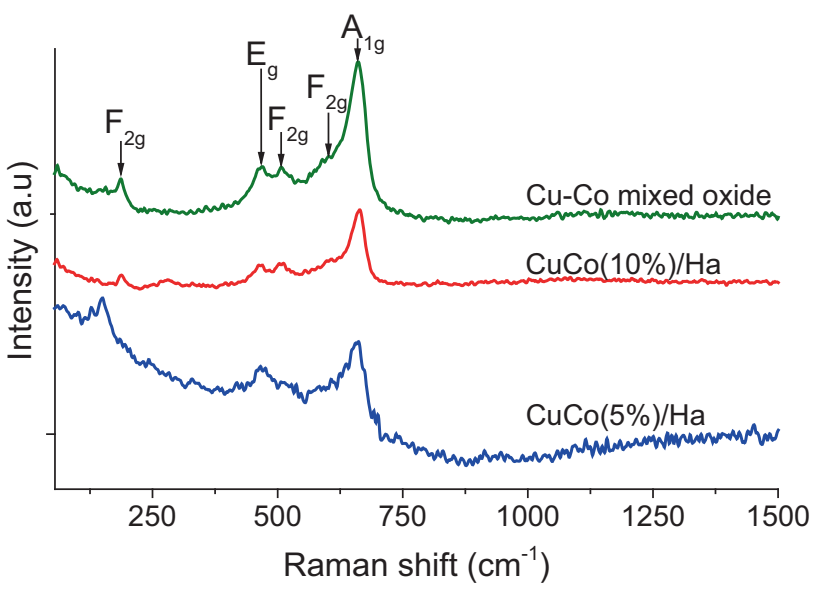

Figure 3. Raman spectra $(\lambda=532 \mathrm{~nm})$ of the catalysts and the $\mathrm{Cu}-\mathrm{Co}$ mixed oxide synthesized as a reference.

related to the tetrahedral sites [44]. A comparison between the spectra of $\mathrm{Cu}-\mathrm{Co}$ mixed oxide (reference) and the catalysts shows slight displacements of the peaks, perhaps as a consequence of differences in size and geometry of the spinel microparticles, isolated or on the support. It is well known that particle size and morphology, among other factors, such as substitutions, affect the strict position of Raman bands. These results confirm the successful formation of $\mathrm{CuCo}_{2} \mathrm{O}_{4}$ on the Ha nanotubes. Thus, it becomes clear that the active sites of these catalysts are particles of $\mathrm{CuCo}_{2} \mathrm{O}_{4}$ supported on $\mathrm{Ha}$.

Irregular grain morphologies of the agglomerates of $\mathrm{Ha}$ and the catalysts can be inferred from SEM analyses (figure 4). These morphologies are different from those of the $\mathrm{Cu}-\mathrm{Co}$ mixed oxide (figure $4 b$ ), which has spheroidal microparticles. Thus, the grain morphology of the catalysts is completely due to $\mathrm{Ha}$, in response to the less content of the active phase and probably an adequate dispersion of the active sites $\left(\mathrm{CuCo}_{2} \mathrm{O}_{4}\right)$ on the support. EDX spectra reflect the elemental composition of the samples, and therefore, the intensities observed for $\mathrm{Al}$ and $\mathrm{Si}$ are in response to the 1:1 ratio of the alumina/silica sheets in the clay mineral. Furthermore, a clear difference between the $\mathrm{Cu}$ and $\mathrm{Co}$ intensities is a consequence of the 1:2 ratio of copper and cobalt in the solids. Representative TEM for Ha (support) and the catalysts are shown in figure 5. A predominant nanotubular morphology is revealed, typical of Ha. These nanotubes are preserved in the synthesized catalysts, an important aspect for the performance of catalysts since the molecular traffic through the solids becomes simplified.

Nitrogen adsorption analyses for $\mathrm{Ha}$ and the catalysts (figure 6) gave isotherms with mixed characteristics of type II/IVa, according to the new IUPAC classification [45]. These isotherms are typical of meso-macroporous solids, and their hysteresis curves (type H1) are characteristic of cylindrical pores. These features are a consequence of the nanotubular morphology of both support and catalysts. Slight changes in the adsorption levels were observed between the catalyst $\mathrm{CuCo}(10 \%)$ and the support, but no important difference 

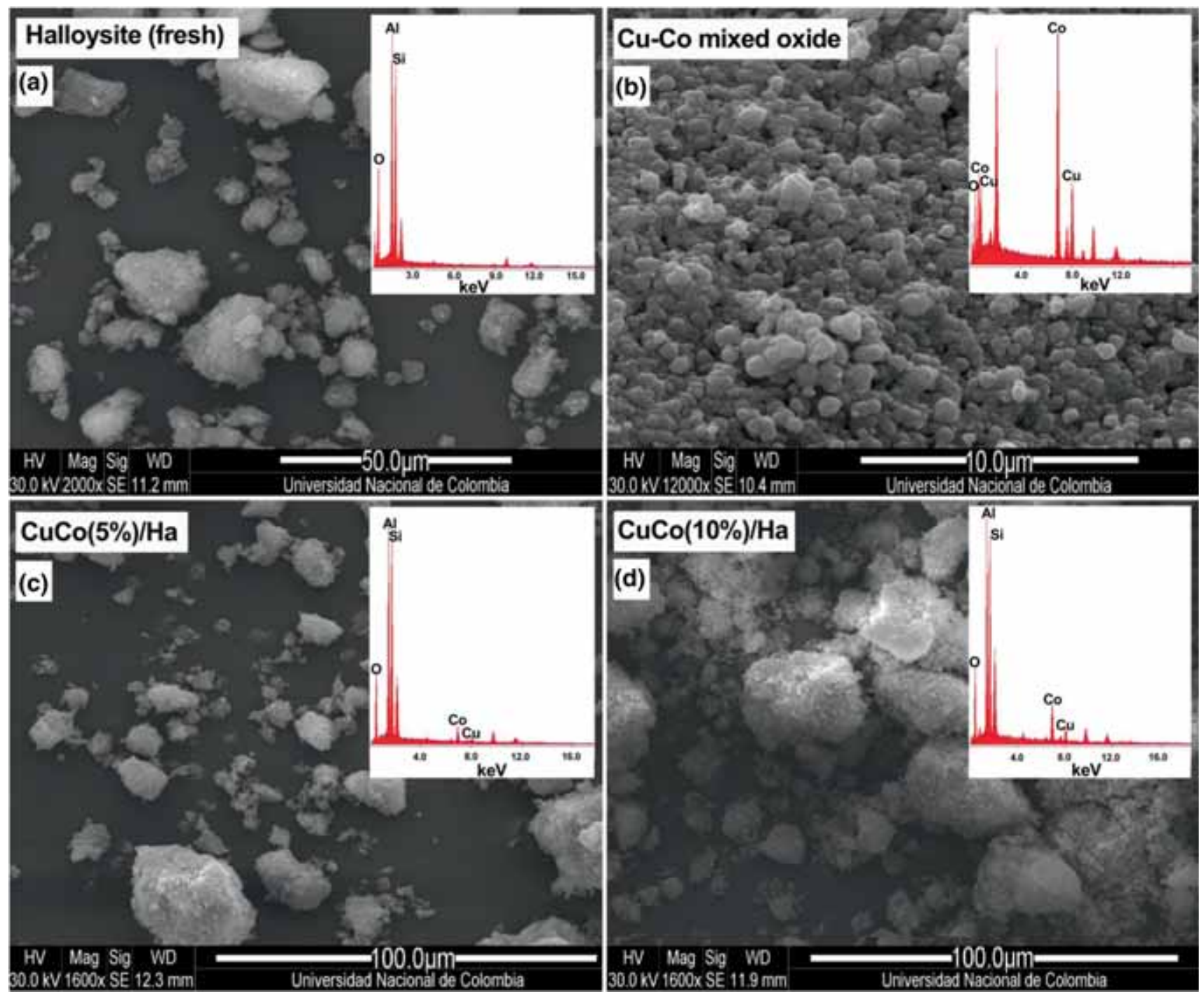

Figure 4. SEM images and EDX analyses of the samples: (a) $\mathrm{Ha}$ (fresh), (b) $\mathrm{Cu}-\mathrm{Co}$ mixed oxide synthesized as a reference, (c) $\mathrm{CuCo}(5 \%) / \mathrm{Ha}$ and (d) $\mathrm{CuCo}(10 \%) / \mathrm{Ha}$.

was observed among the catalyst $\mathrm{CuCo}(5 \%)$ and fresh or calcined Ha. These results confirm that the adsorption level is not reduced by the calcination. A decrease in the $\mathrm{N}_{2}$ adsorption is a consequence of the $\mathrm{Cu}-\mathrm{Co}$ oxide deposition in a considerable amount (10\%). The textural properties of these solids are summarized in table 2 . According to the table, only the BET surface area of the solid CuCo (10\%) $\left(34 \mathrm{~m}^{2} \mathrm{~g}^{-1}\right)$ was lower than the support $\left(43 \mathrm{~m}^{2} \mathrm{~g}^{-1}\right)$. Although this reduction is evident for this catalyst, the predominant pore size in the mesopore range moved only from 400 to $320 \AA$ for both catalysts (table 2). Indeed, figure 7 reveals some variations in pore size distributions. In this figure, it is clear that while the micropore population decreases, the mesopore population increases, when different amounts of $\mathrm{Cu}-\mathrm{Co}$ oxide are impregnated. According to these pore size distributions, the porous structure of Ha was not altered by the calcination, but the impregnated $\mathrm{Cu}-\mathrm{Co}$ oxide reduces the pore width in the catalysts. However, by comparing the molecular dimensions of the dyes (17 $\AA$ for BR-46 and $29 \AA$ for RY-145, calculated with software PC Spartan Pro) with predominant pore diameters of the catalysts, it is possible to conclude that the pore structure is enough to allow a good diffusion of the dye molecules and their oxidation by-products through the pores.

\subsection{Catalytic degradation of dyes}

Catalytic conversions of RY-145 and BR-46, using the catalysts $\mathrm{CuCo}(5 \%) / \mathrm{Ha}$ and $\mathrm{CuCo}(10 \%) / \mathrm{Ha}$, are plotted in figures 8 and 9, respectively. Evidently, these catalysts are active for the oxidation of dyes, reaching up to $93.1 \pm 2.2$ and $54.4 \pm 2.0 \%$ of dye conversion for RY-145 and BR46 , respectively. Catalytic conversions of the catalysts are higher and well differentiated regarding the contribution of the 

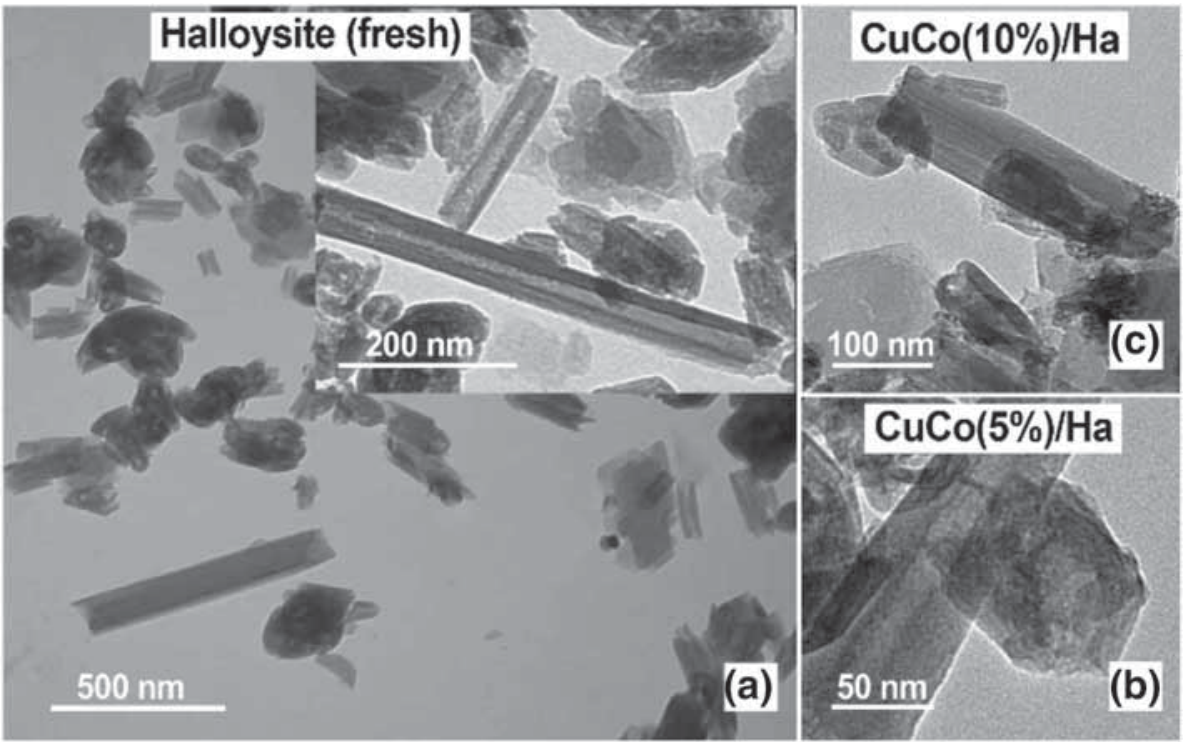

Figure 5. TEM images of the samples: (a) $\mathrm{Ha}$ (fresh), (b) $\mathrm{CuCo}(5 \%) / \mathrm{Ha}$ and (c) $\mathrm{CuCo}$ (10\%)/Ha.

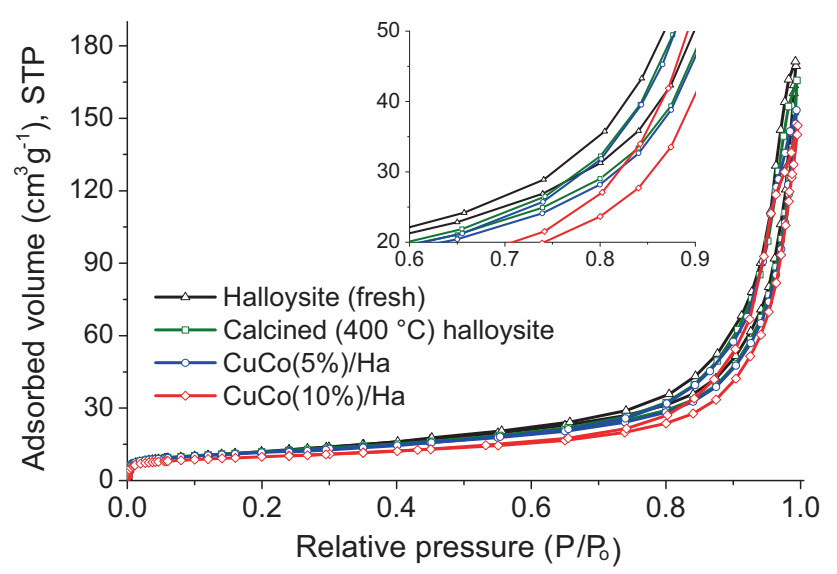

Figure 6. Nitrogen adsorption-desorption isotherms at $77 \mathrm{~K}$ of the catalysts $\mathrm{CuCo}(5 \%) / \mathrm{Ha}$ and $\mathrm{CuCo}(10 \%) / \mathrm{Ha}$, and for $\mathrm{Ha}$ (both fresh and calcined).

support. In addition, high content of copper-cobalt oxide $(10 \%)$ in the catalyst clearly induces a higher catalytic conversion than that of the catalyst with less content $(5 \%)$, confirming the catalytic activity of the $\mathrm{CuCO}_{2} \mathrm{O}_{4}$ phase. This prominent effect is a consequence of more active sites on the Ha nanotubes. On the other hand, the catalytic contribution of the support is perhaps a result of small quantities of other elements, such as iron, in Ha. A content of $0.52 \%$ of $\mathrm{Fe}_{2} \mathrm{O}_{3}$ is observed in table 1. A part of this iron amount can be outside the clay mineral structure, as true oxides. Iron oxides are recognized as active sites to decompose the hydrogen peroxide, producing ${ }^{\circ} \mathrm{OH}$ radicals $[26,46]$. These radicals can oxidize the organic molecules, contributing to the catalytic conversions. This contribution from the iron oxides contained in natural clays used as supports of catalysts, has been already observed in previous studies about catalytic degradation of phenol [47,48]. In addition, Garrido-Ramirez et al [49] reported the catalytic contribution of two synthetic allophanes (amorphous clays with two different $\mathrm{SiO}_{2} / \mathrm{Al}_{2} \mathrm{O}_{3}$ ratios, 1 and 2.2) in the total oxidation of phenol in aqueous solutions. In that case, the authors explained that such contributions as a result of the textural and structural characteristics of the surface, favouring the adsorption of more phenol molecules, presumably through hydrogen bonding with the surface silanol groups [49]. On the other hand, although both dyes (RY145 and BR-46) are widely recognized as very recalcitrant, it is more difficult to oxidize the BR-46 dye under these experimental conditions. TOC and TN conversions confirm the incomplete oxidation of these dyes to $\mathrm{CO}_{2}$, water and other soluble inorganic species. According to these results, about $59.5 \pm 1.8 \%$ of TOC conversion and $50.7 \pm 2.3 \%$ of TN conversion were achieved for RY-145 when this dye was oxidized with the catalyst $\mathrm{CuCo}(10 \%) / \mathrm{Ha}$. However, only $33.9 \pm 1.4 \%$ of TOC conversion and $16.9 \pm 1.2 \%$ of $\mathrm{TN}$ conversion were achieved for BR-46 on using the same catalyst.

These differences among TOC, TN and dye conversions for RY-145 and BR-46 reveal that some fraction of intermediates remains in the solution under an incomplete reaction pathway. A higher difference between the TOC and TN conversions was observed for the catalytic oxidation of BR-46, clearly indicating that a significant fraction of the converted molecules remained as nitrogenated compounds and soluble salts. This result confirms the higher refractory performance of the BR-46 dye. Although the total oxidation of dyes to $\mathrm{CO}_{2}$ and $\mathrm{H}_{2} \mathrm{O}$ was not achieved completely, the successful performance of the $\mathrm{CuCo} / \mathrm{Ha}$ catalysts is noteworthy due to the high catalytic degradation levels using a very small quantity of 
Table 2. Textural properties of $\mathrm{Ha}$ (fresh and calcined) and $\mathrm{CuCo} / \mathrm{Ha}$ catalysts.

\begin{tabular}{lccc}
\hline Solid & BET surface area $\left(\mathrm{m}^{2} \mathrm{~g}^{-1}\right)$ & Total pore volume $\left(\mathrm{cm}^{3} \mathrm{~g}^{-1}\right)^{\mathrm{a}}$ & Predominant pore size $($ diameter, $\AA)$ \\
\hline $\mathrm{Ha}($ fresh) & 43 & 0.27 & $40,100,200,400$ \\
$\mathrm{Ha}($ calcined) & 42 & 0.26 & $40,100,200,400$ \\
$\mathrm{CuCo}(5 \%) / \mathrm{Ha}$ & 41 & 0.24 & $40,110,190,320$ \\
$\mathrm{CuCo}(10 \%) / \mathrm{Ha}$ & 34 & 0.23 & $40,110,190,320$ \\
\hline
\end{tabular}

${ }^{\mathrm{a}}$ Total pore volume was determined by the Gurvitsch method.

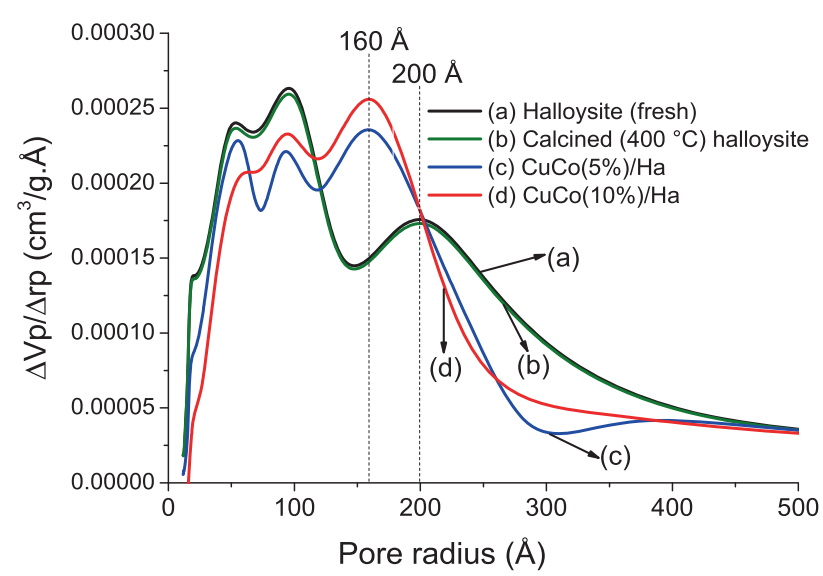

Figure 7. BJH pore size distributions for the $\mathrm{Ha}$ (fresh and calcined) and the catalysts $\mathrm{CuCo}(5 \%) / \mathrm{Ha}$ and $\mathrm{CuCo}(10 \%) / \mathrm{Ha}$.

solids ( $80 \mathrm{mg}$ of catalyst for $225 \mathrm{ml}$ of dye solution). In addition, the mild reaction conditions and the truly lowleaching of metals (cobalt and copper) during the catalytic tests are also important aspects to be highlighted. Leaching values lower than $1.54 \pm 0.05$ and $0.88 \pm 0.02 \mathrm{mg} \mathrm{l}^{-1}$ were measured for cobalt and copper, respectively (table 3). Low-leaching levels indicate a good stability of the solids and confirm the heterogeneous catalytic process.
It is well accepted that transition metal oxides decompose hydrogen peroxide to yield hydroxyl and perhydroxyl radicals ( $\mathrm{OH}$ and $\mathrm{HO}_{2}{ }^{\circ}$ ) [26,32]. In such case, $\mathrm{CuCo}_{2} \mathrm{O}_{4}$ (the active phase) produces these radicals that attack the complex molecules of dyes through an oxidation pathway yielding several middle- and small-sized molecules, inorganic species, $\mathrm{CO}_{2}$ and $\mathrm{H}_{2} \mathrm{O}$. The total conversion of these dyes to $\mathrm{CO}_{2}$ and water is the desired result, but it is difficult to obtain due to the stable character of these azo-dyes. According to the literature [50], some of the intermediates are aniline, phenol, phthalic acid, oxalic acid, acetic acid and formic acid, and inorganic anions such as $\mathrm{NO}_{3}^{-}, \mathrm{NO}_{2}^{-}, \mathrm{Cl}^{-}, \mathrm{SO}_{4}^{2-}$ and $\mathrm{NH}_{4}^{+}$.

It is not possible to compare these catalysts with other solids under the same conditions, but similar results were obtained for the total degradation (to $\mathrm{CO}_{2}$ and water) of RY-145 in a previous work, under comparable conditions of dye concentration, temperature, pressure and catalyst mass, but with higher quantity of hydrogen peroxide and UV irradiation on iron(III)- $\mathrm{TiO}_{2}$-delaminated montmorillonite [2]. Therefore, in the present work, more efficient catalysts were used, without irradiation and with lower amounts of hydrogen peroxide. Other authors have achieved higher degradation levels of RY145 using UV-enhanced ozonation with a high power UV lamp (e.g., 175 W) [50]. However, Gül and Özcan-Yıldırım [15] only achieved $43.8 \%$ of TOC removal (for RY-145)
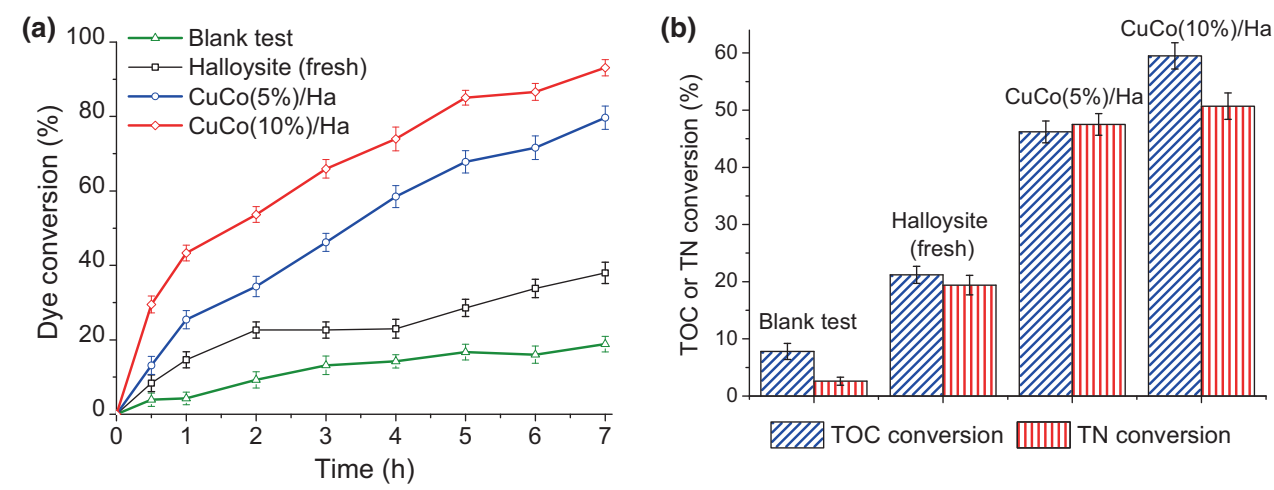

Figure 8. Catalytic degradation of RY-145 under mild conditions $\left(18 \mathrm{mg}^{-1}, 25^{\circ} \mathrm{C}\right.$, ambient pressure, $\mathrm{pH}=4)$ using the synthesized catalysts $(80 \mathrm{mg}$ ). (a) Catalytic conversion of dye during the reaction. (b) TOC and TN conversions at the end of the reaction. 

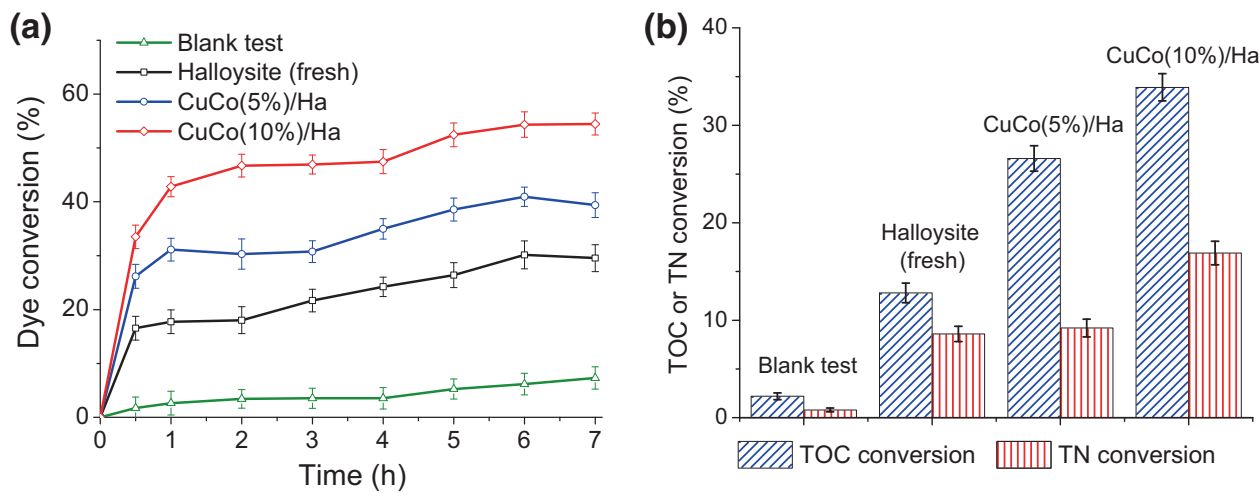

Figure 9. Catalytic degradation of BR-46 under mild conditions $\left(23 \mathrm{mg} 1^{-1}, 25^{\circ} \mathrm{C}\right.$, atmosphere pressure, $\mathrm{pH}=4$ ) using the synthesized catalysts $(80 \mathrm{mg})$. (a) Catalytic conversion of dye during the reaction. (b) TOC and TN conversions at the end of the reaction.

Table 3. Metal (copper or cobalt) leaching of the solids through the catalytic tests $(7 \mathrm{~h})$.

\begin{tabular}{lcc}
\hline Catalytic test $($ system at $\mathrm{pH}=4)$ & Cobalt concentration $\left(\mathrm{mg} \mathrm{l}^{-1}\right)$ & Copper concentration $\left(\mathrm{mg}^{-1}\right)$ \\
\hline $\mathrm{Ha}+\mathrm{RY}-145+\mathrm{H}_{2} \mathrm{O}_{2}$ & $<0.01$ & $<0.005$ \\
$\mathrm{CuCo}(5 \%) / \mathrm{Ha}+\mathrm{RY}-145+\mathrm{H}_{2} \mathrm{O}_{2}$ & $1.50 \pm 0.04$ & $0.88 \pm 0.02$ \\
$\mathrm{CuCo}(10 \%) / \mathrm{Ha}+\mathrm{RY}-145+\mathrm{H}_{2} \mathrm{O}_{2}$ & $1.54 \pm 0.05$ & $0.44 \pm 0.01$ \\
$\mathrm{Ha}+\mathrm{BR}-46+\mathrm{H}_{2} \mathrm{O}_{2}$ & $<0.01$ & $<0.005$ \\
$\mathrm{CuCo}(5 \%) / \mathrm{Ha}+\mathrm{BR}-46+\mathrm{H}_{2} \mathrm{O}_{2}$ & $1.49 \pm 0.04$ & $0.86 \pm 0.02$ \\
$\mathrm{CuCo}(10 \%) / \mathrm{Ha}+\mathrm{BR}-46+\mathrm{H}_{2} \mathrm{O}_{2}$ & $1.44 \pm 0.04$ & $0.47 \pm 0.01$ \\
\hline
\end{tabular}

by processes with $\mathrm{O}_{3} / \mathrm{H}_{2} \mathrm{O}_{2} / \mathrm{UV}(20 \mathrm{~W})$. In other studies, UV-assisted methods have been used to only decolourize the solutions of RY-145 or BR-46 [20,51].

\section{Conclusion}

Two catalysts of $\mathrm{Cu}-\mathrm{Co}$ oxide (1:2 molar ratio of metals) supported on $\mathrm{Ha}$ nanotubes, $\mathrm{CuCo}(5 \%) / \mathrm{Ha}$ and $\mathrm{CuCo}$ $(10 \%) / \mathrm{Ha}$, were successfully synthesized. The catalysts were characterized by several physicochemical techniques, and $\mathrm{CuCo}_{2} \mathrm{O}_{4}$ (a substituted copper-cobalt spinel structure) was identified as the active phase. Nanotubular morphology was confirmed in the catalysts, which were active for the CWPO of two real-textile azo-dyes, RY-145 and BR-46. Degradation of these dyes was achieved under mild conditions (diluted solutions, atmospheric pressure, $25^{\circ} \mathrm{C}$ and very low amount of catalyst), with $93.1 \pm 2.2$ and $54.4 \pm 2.0 \%$ of dye conversion for RY-145 and BR-46, respectively. Significant values of TOC removal were obtained, revealing a total oxidation of a significant fraction of dyes to $\mathrm{CO}_{2}$ and $\mathrm{H}_{2} \mathrm{O}$. A more difficult mineralization was observed for BR-46, an extremely recalcitrant compound. In all cases, the catalysts were stable and very low metal leaching values were detected by atomic absorption. Taking into account the above-mentioned results, it can be concluded that the synthesized solids are promising heterogeneous catalysts to be optimized and used in the environmental remediation of azo-dye wastewaters.

\section{Acknowledgements}

We gratefully acknowledge Universidad Nacional de Colombia for supplying the resources for this scientific research. This work was developed in the Lab-DRES (Laboratorio de Diseño y Reactividad de Estructuras Sólidas, UNBogotá), and at the Engineering and Architecture Faculty (UN-Manizales).

\section{References}

[1] Abdel-Raouf N, Al-Homaidan A A and Ibraheem I B M 2012 Saudi J. Biol. Sci. 19257

[2] Torres-Luna J A, Carriazo J G and Sanabria N R 2016 Environ. Technol. 371346

[3] Zaharia C and Suteu D 2012 in Puzyn T (ed.) Organic pollutants ten years after the Stockholm convention environmental and analytical update (Croatia: InTech Europe) p 55

[4] Gómez M J, Pazos F, Guijarro F J, de Lorenzo V and Valencia A 2007 Mol. Syst. Biol. 31 
[5] Alves de Lima R O, Bazo A P, Salvadori D M F, Rech C M, de Palma Oliveira D and de Aragão Umbuzeiro G 2007 Mutat. Res. Genet. Toxicol. Environ. Mutagen. 62653

[6] Bouatay F, Dridi-Dhaouadi S, Drira N and Farouk Mhenni M 2016 Desalin. Water Treat. 5713561

[7] Byberg R, Cobb J, Diez Martin L, Thompson R W, Camesano T, Zahraa O et al 2013 Environ. Sci. Pollut. Res. 203570

[8] Jaafarzadeh N, Takdastan A, Jorfi S, Ghanbari F, Ahmadi M and Barzegar G 2018 J. Mol. Liq. 256462

[9] Demir N, Gündüz G and Dükkancı M 2015 Environ. Sci. Pollut. Res. 223193

[10] Natarajan S, Bajaj H C and Tayade R J 2018 J. Environ. Sci. 65201

[11] Balapure K, Bhatt N and Madamwar D 2015 Bioresour. Technol. 1751

[12] de Souza S M, Bonilla K A S and de Souza A A U 2010 J. Hazard. Mater. 17935

[13] Ong S-A, Uchiyama K, Inadama D, Ishida Y and Yamagiwa K 2010 Bioresour. Technol. 1019049

[14] Zollinger H 2003 Color chemistry: syntheses, properties, and applications of organic dyes and pigments (Zurich: Wiley$\mathrm{VCH})$

[15] Gül Ş and Özcan-Yıldırım Ö 2009 Chem. Eng. J. 155684

[16] Patil N N and Shukla S R 2015 J. Water Process. Eng. 7314

[17] Parvaresha V, Hashemib H, Khodabakhshic A and Sedehid M 2018 Desalin. Water Treat. 111345

[18] Caner N, Kiran I, Ilhan S, Pinarbasi A and Iscen C F 2011 Sep. Sci. Technol. 462283

[19] Abd El-Rahim W, Moawad H, Abdel Azeiz A and Sadowsky M 2017 J. Biotechnol. 26011

[20] Fahimirad B, Asghari A and Rajabi M 2017 Spectrochim. Acta A: Mol. Biomol. Spectrosc. 17958

[21] Fu J and Kyzas G Z 2014 Chinese J. Catal. 351

[22] Ghuge S P and Saroha A K 2018 J. Water Process. Eng. 23217

[23] Bouafia-Chergui S, Oturan N, Khalaf H and Oturan M A 2010 J. Environ. Sci. Health, A: Toxic/Hazard. Subst. Environ. Eng. 45622

[24] Dong J, Dong H, Han L, Fu B, Chen Y and Zhan Y 2015 Desalin. Water Treat. 561056

[25] Baloyi J, Ntho T and Moma J 2018 RSC Adv. 85197

[26] Bokare A D and Choi W 2014 J. Hazard. Mater. 275121

[27] Bao X, Qin Z, Zhou T and Deng J 2018 J. Environ. Sci. 65236

[28] Reza K M, Kurny A and Gulshan F 2016 Int. J. Environ. Sci. Technol. 7325

[29] Covinich L G, Massa P, Fenoglio R J and Area M C 2016 Crit. Rev. Environ. Sci. Technol. 461745
[30] Munoz M, de Pedro Z M, Casas J A and Rodriguez J J 2015 Appl. Catal. B: Environ. 176-177 249

[31] Vela-Monroy C A, Saavedra-Alemán M J and Carriazo-Baños J G 2016 Tecno Lógicas 1913

[32] Wang N, Zheng T, Zhang G and Wang P 2016 J. Environ. Chem. Eng. 4762

[33] Yu C, Li G, Wei L, Fan Q, Shu Q and Yu J C 2014 Catal. Today 224154

[34] Liu S, Gu Y, Wang S, Zhang Y, Fang Y, Johnson D M et al 2013 Chin. Sci. Bull. 582340

[35] Carriazo J G, Bossa-Benavides L F and Castillo E 2012 Quím. Nova 351101

[36] Carrillo A M and Carriazo J G 2015 Appl. Catal. B: Environ. 164443

[37] Molano W A, Cárdenas J C, Sierra C A, Carriazo J G and Ochoa-Puentes C 2018 ChemistrySelect 34430

[38] Carrillo A M, Urruchurto C M, Carriazo J G, Moreno S and Molina R A 2014 Rev. Mex. Ing. Quím. 13563

[39] Nath N C D, Debnath T, Kim E-K, Ali Shaikh M A and Lee J-J 2018 Electrochim. Acta 273474

[40] Palacios-Hernández T, Hirata-Flores G A, Contreras-López O E, Mendoza-Sánchez M E, Valeriano-Arreola I, GonzálezVergara E et al 2012 Inorg. Chim. Acta 392277

[41] Ercolino G, Grodzka A, Grzybek G, Stelmachowski P, Specchia S and Kotarba A 2017 Top. Catal. 60333

[42] Liu Z-Q, Xiao K, Xu Q-Z, Li N, Su Y-Z, Wang H-J et al 2013 RSC Adv. 34372

[43] Silambarasan M, Padmanathan N, Ramesh P and Geetha D 2016 Mater. Res. Express 31

[44] Alvarez A, Ivanova S, Centeno M A and Odriozola J A 2012 Appl. Catal. A: Gen. 431-432 9

[45] Thommes M, Kaneko K, Neimark A V, Olivier J P, RodriguezReinoso F, Rouquerol J et al 2015 Pure Appl. Chem. 871051

[46] Tartaj P, Morales M P, Gonzalez-Carreño T, VeintemillasVerdaguer S and Serna C J 2011 Adv. Mater. 235243

[47] Carriazo J G, Molina R and Moreno S 2008 Appl. Catal. A 334 168

[48] Carriazo J G, Guélou E, Barrault J, Tatibouet J M, Molina R and Moreno S 2005 Catal. Today 107-108 126

[49] Garrido-Ramirez E G, Sivaiah M V, Barrault J, Valange S, Theng B K G, Ureta-Zañartu M S et al 2012 Microporous Mesoporous Mater. 162189

[50] Song S, Xu X, Xu L, He Z, Ying H, Chen J et al 2008 Ind. Eng. Chem. Res. 471386

[51] Alahiane S, Qourzal S, El-Ouardi M, Abaamrane A and Assabbane A 2014 Am. J. Anal. Chem. 5445 